Лагодієнко В.В. Продовольча безпека Причорноморського регіону: стан, тенденції, перспективи

Лагодієнко Володимир Вікторович

д.е.н., професор,

завідувач кафедри маркетингу, підприємництва і торгівлі, Одеська національна академія харчових технологій,

\title{
ПРОДОВОЛЬЧА БЕЗПЕКА ПРИЧОРНОМОРСЬКОГО РЕГІОНУ: СТАН, ТЕНДЕНЦЇ, ПЕРСПЕКТИВИ
}

В статті досліджується рівень продовольчої безпеки Причорноморського регіону. Виявлено, що за фактичними значеннями індикатору «добова енергетична цінність раціонулюдини» рівеньпродовольчої безпеки в Одеській та Херсонській областях - задовільний, а у домогосподарства I, II і IV децильних груп Миколаївської області - незадовільний. Стверджується, що за фактичними значеннями індикаторів «забезпечення раціону людини основними видами продуктів», «економічна доступність продуктів», «ємність внутрішнього ринку окремих продуктів» рівень продовольчої безпеки Причорноморського регіону незадовільний. Робиться висновок, що для досягнення задовільного рівня продовольчої безпеки Причорноморського регіону необхідно перейти від стимулювання пропозиції аграрної продукції до стимулювання продовольчого попиту.

Ключові слова: продовольча безпека, регіон, домогосподарство, енергетична цінність, тимчасовий голод, економічна доступність, продовольча допомога.

Постановка проблеми. Стратегічний курс на розбудову соціально-орієнтованої ринкової економіки України ставить на порядок денний питання суттєвого підвищення рівня життя населення країни. що особливо актуально в світлі підписання Угоди про асоціацію Україна-ЄС, в якій зобов'язанням по досягненню європейських стандартів рівня життя країни-кандидата відводиться ключова роль. Наразі одним із найбільш проблемних моментів внутрішньої соціальної політики нашої держави в частині продовольчої безпеки громадян, $\epsilon$ забезпечення повноцінної економічної доступності продуктів харчування. Відтак, виявлення чинників, які перешкоджають досягненню продовольчої безпеки країни, регіону, окремого домогосподарства та розробка заходів із їх нейтралізації було і залишається актуальною науковою проблемою.

Аналіз останніх досліджень i публікацій. Зважаючи на те, що продовольча безпека формалізує систему харчового життєзабезпечення людини та відображає умови її виживання як біологічної істоти, і у зв'язку із гуманізацією соціальних відносин усіх рівнів, вона $є$ актуальної науковою темою осьужепонадсорок років. Середзакордонних вчених слід виділити роботи Гопкінса Р., Тулліса Ф. та Холліста В. (Hopkins R. F., Tullis F. L., Hollist W. L., 1986) [1], Максвела C. та Франкенбергера T. (Maxwell S., Frankenberger Т., 1992) [2], Йоахіма вон Брауна, Свамінатана M. та Росегранта M. (Joachim von Braun, M. S. Swaminathan, and Mark W. Rosegrant, 2005) [3], Менійонга В. і Геркена А. (Manyong V. М., Gerken A., 2009) [4], Чандра А. і Лонтоха Л. (Chandra A. C., Lontoh A. L., 2010) [5], Блейна 3., Беюджі Р., Летарка Г. і Конате C. (Blein R., Beaujeu R., Leturque H., Konat S., 2012) [6], Рампа Ф. і ван Вік Л.-А. (Rampa F. and van Wyk L.-A.) [7], Гейслер M. (Giesler M.) [8] та ін. Серед вітчизняних вчених звертають на себе увагу роботи Гойчук О. І. [9], Власова В. І. [10], Мудрака Р. П. [11], Шубравської О. В., Молдаван Л. В., Пасхавера Б. Й. [12] та ін. Однак, не зважаючи на достатньо глибоку науково-методичну розробку досліджуваної проблеми, окремі її аспекти залишаються недостатньо опрацьованими. Специфічні особливості функціонування національних економік, продиктовані унікальним географічним розташуванням, відмінними природно-кліматичними 
умовами, рівнем соціально-економічного розвитку та політичної культури, ступенем інтеграції в глобальне середовище, історичними, ментальними, релігійними та іншими факторами, унеможливлюють розробки універсального інструмента-рію попередження та ліквідації продовольчої небезпеки. Адже, якщо у питанні визначення поняття «продовольча безпека» досягнуто певний компроміс, то стосовно ії рівнів та способів забезпечення досі точиться дискусія. Що й обумовлює необхідність подальших досліджень у даному напрямку.

Мета дослідження. Метою статті $\epsilon$ оцінка стану продовольчої безпеки Причорноморського регіону України, виявлення тенденцій та, у разі необхідності, обґрунтування заходів із її підвищення.

Основні результати дослідження. В Законі України «Про державну підтримку сільського господарства України» продовольча безпека - це захищеність життєвих інтересів людини, яка виражається у гарантуванні державою безперешкодного економічного доступу до продуктів харчування з метою підтримання ії звичайної життєвої діяльності [13].

Відповідно до Постанови Кабінету Міністрів України від 5 грудня 2007 року №1379 «Деякі питання продовольчої безпеки» індикаторами, що характеризують стан продовольчої безпеки держави (регіону) $\epsilon$ :

1) добова енергетична цінність раціону людини. Граничний (пороговий) критерій становить 2500 кал на добу. При цьому 55\% добового раціону повинне забезпечуватися за рахунок споживання продуктів тваринного походження;

2) забезпечення раціону людини основними видами продуктів. Визначається як співвідношення між фактичним споживанням окремого продукту та його раціональною нормою;

3) достатність запасів зерна у державних резервах. Граничним (порого-вим) критерієм для зазначеного показника вважається його 17-відсотковий рівень, що відповідає 60 дням споживання;

4) економічна доступність продуктів. Граничним (пороговим) критерієм для зазначеного показника $є 60 \%$;

5) диференціація вартості харчування за соціальними групами. Розрахо-вується як співвідношення між вартістю харчування 20 відсотків домогоспо-дарств $з$ найбільшими доходами та вартістю харчування 20 відсотків домогос-подарств з найменшими доходами;

6) ємність внутрішнього ринку окремих продуктів. Визначається у нату-ральному виразі як добуток споживання певного продукту та середньорічної чисельності населення;

7) продовольча незалежність за окремим продуктом. Граничним (пороговим) критерієм для зазначеного показника $є 30 \%$ [14].

Для нашого аналізу особливий інтерес представляють показники для яких є порогові значення.

Таблиця 1

Енергетична цінність спожитих продуктів харчування у домогосподарствах, у середньому за добу у розрахунку на одну особу, ккал

\begin{tabular}{|l|c|c|c|c|c|c|c|c|}
\hline \multirow{2}{*}{ Область } & \multicolumn{7}{|c|}{ Рік } \\
\cline { 2 - 9 } & 2010 & 2011 & 2012 & 2013 & 2014 & 2015 & 2016 & 2017 \\
\hline Миколаївська & 3041 & 3078 & 3132 & 3107 & 2987 & 2836 & 2788 & 2685 \\
\hline Одеська & 2839 & 2937 & 2872 & 2843 & 2888 & 2801 & 2723 & 2694 \\
\hline Херсонська & 3020 & 3154 & 3120 & 3107 & 3112 & 2951 & 2902 & 2858 \\
\hline Україна & 2933 & 2951 & 2954 & 2969 & 2939 & 2799 & 2742 & 2707 \\
\hline
\end{tabular}


Лагодієнко В.В. Продовольча безпека Причорноморського регіону: стан, тенденції, перспективи

\section{Раціональна норма та фактичне споживання базових видів продовольства в 2017рр., в середньому кг на 1 особу в рік [15]}

\begin{tabular}{|c|c|c|c|c|c|c|c|c|c|}
\hline \multirow{3}{*}{ Продукт } & \multirow{3}{*}{$\begin{array}{c}\text { Раціональна } \\
\text { норма спо- } \\
\text { живання }\end{array}$} & \multicolumn{6}{|c|}{ Область } & \multirow{2}{*}{\multicolumn{2}{|c|}{ Україна }} \\
\hline & & \multicolumn{2}{|c|}{ Миколаївська } & \multicolumn{2}{|c|}{ Одеська } & \multicolumn{2}{|c|}{ Херсонська } & & \\
\hline & & $2014 p$. & $2017 p$. & $2014 p$. & $2017 p$. & 2014p. & $2017 p$. & $2014 p$. & $2017 p$. \\
\hline $\begin{array}{l}\text { М'ясо і } \\
\text { м'ясопродукти }\end{array}$ & 53 & 48,2 & 48,1 & 49 & 48 & 53,6 & 53,1 & 54,1 & 51,7 \\
\hline $\begin{array}{l}\text { Молоко і молочні } \\
\text { продукти }\end{array}$ & 300 & 227,2 & 202 & 205,5 & 180,7 & 211 & 204,4 & 222,8 & 200 \\
\hline Яйця, шт. & 220 & 305 & 261 & 293 & 268 & 310 & 268 & 310 & 273 \\
\hline Риба і рибопродукти & 13 & 11,5 & 10,6 & 15,7 & 14,7 & 12,7 & 12,4 & 11,1 & 10,8 \\
\hline Цукор & 24 & 37,3 & 30,3 & 37,2 & 30,6 & 41,0 & 34,9 & 36,3 & 30,4 \\
\hline $\begin{array}{l}\text { Олія та інші рослинні } \\
\text { жири }\end{array}$ & 10 & 14,4 & 12,9 & 14,1 & 14,2 & 13 & 11,6 & 13,1 & 11,7 \\
\hline Картопля & 95 & 117,8 & 115,6 & 115,1 & 107,1 & 144,1 & 139,4 & 141 & 143,4 \\
\hline Овочі і баштанні & 110 & 188 & 176,4 & 173 & 150,1 & 185,1 & 163,9 & 163,2 & 159,7 \\
\hline $\begin{array}{l}\text { Фрукти, ягоди, } \\
\text { горіхи, виноград }\end{array}$ & 80 & 52,6 & 51,3 & 58 & 57,6 & 53,4 & 48,1 & 52,3 & 52,8 \\
\hline $\begin{array}{l}\text { Хліб і хлібні } \\
\text { продукти }\end{array}$ & 95 & 115,2 & 102 & 108,3 & 104,4 & 122,4 & 115 & 108,5 & 100,8 \\
\hline
\end{tabular}

У звітному періоді в Миколаївській та Одеській областях середній показник енергетичної цінності спожитих продуктів харчування був вищий за порогове значення 2500 ккал на добу, але - нижчий за середнє по країні (2939 ккал) (табл. 1). При цьому в усіх областях Причорноморського регіону відслідковується тривожна тенденція - починаючи 3 2013 року скорочується кількість спожитих продуктів харчування. Фактичні показники звітного періоду свідчать про відсутність у Причорноморському регіоні хронічного недоїдання. Разом з тим, середнє значення показника «енергетична цінність спожитих продуктів харчування у домогосподарствах» у Миколаївській області свідчить про те, що у звітному періоді тут були домогосподарства, які стикалися із проблемою тимчасового недоїданні. Це домогосподарства I, II i IV децильних груп із середнім зна-ченням енергетичної цінності раціону 2413, 2357 і 2412 ккал за добу на одну особу відповідно.

Харчовий раціон жителів Причорноморського регіону - не збалансований по головних поживних речовинах (табл. 2). Так, не виконується умова про частку протеїнів у харчовому раціоні (їжа тваринного походження 55\% від 2500 кал). Також нижче норми споживаються вітаміновмісні продукти харчування свіжі фрукти, ягоди і виноград.

Відслідкувати динаміку третього індикатора продовольчої безпеки При-чорноморського регіону на базі доступних статистичних даних не видається можливим. І ось чому. В інформаційній базі Державної служби статистики кі-лькість кінцевих запасів продовольчого зерна подається як продукція на зберіганні в усіх ринкових агентів (сільськогосподарські підприємства, зернотрейдери, держава); достовірні дані про запаси продовольчого зерна в сільських домогосподарствах - відсутні. Натомість даних щодо точної кількості продовольчого зерна у державному та регіональних матеріальних резервах у вільному доступі немає. Крім того, щорічні регіональні баланси зернових та зернобобових культур представлені даними лише по сільськогосподарських підприємствах і не розшифровуються по видах продукції (продовольче і фуражне зерно).

Одним із найбільш критичних показників стану продовольчої безпеки виявився показник економічної доступності продовольства (табл. 3). 
Таблиця 3

Частка витрат на продовольство в структурі сукупних витрат домогосподарств, \% [16]

\begin{tabular}{|l|c|c|c|c|c|c|c|c|}
\hline \multirow{2}{*}{ Область } & \multicolumn{9}{|c|}{ Рік } \\
\cline { 2 - 9 } & 2010 & 2011 & 2012 & 2013 & 2014 & 2015 & 2016 & 2017 \\
\hline Миколаївська & 53,9 & 51,8 & 52,3 & 55 & 54,2 & 56,4 & 51,8 & 50,2 \\
\hline Одеська & 59,2 & 64,1 & 61,6 & 59,3 & 60,9 & 60,8 & 58,9 & 56,6 \\
\hline Херсонська & 59,9 & 62,3 & 62,4 & 63,7 & 62,5 & 62,1 & 56,6 & 55,5 \\
\hline Україна & 61,2 & 60,7 & 59,1 & 59,3 & 60,3 & 56,4 & 52,7 & 51 \\
\hline
\end{tabular}

у двох областях Причорноморського регіону - Одеській і Херсонській, у звітному періоді він виявився дуже близьким до порогового значення.

Прямим наслідком скорочення споживання основних продуктів харчу-вання та критично низького рівня економічної доступності продовольства для жителів областей Причорноморського регіону $\epsilon$ низька фактична ємність біль-шості сегментів продовольчого ринку (табл. 4).

Як бачимо населення трьох областей в 2017p. недоспожило 17,4 тис. т м'яса та м'ясопродуктів, 497,3 тис. т молока та молочних продуктів, 119,8 тис. т фруктів, ягід, горіхів і винограду тощо. I це - одна із головних причин низького рівня інвестування у відповідні галузі сільськогосподарського виробництва регіону - у виробництво продукції для ринків із дефіцитом попиту інвестиції не надходять. По останньому показнику продовольчої безпеки продовольча незалежність за окремим продуктом, необхідно зробити кілька зауважень. По-перше, він визначається для ринку країни в цілому, а не кожного місцевого (обласного) ринку окремо.

Адже імпортна продукція заходить на обласні ринки як напряму (із-за кордону), так і завозиться з інших областей. Те ж саме стосується і експорту. По-друге. В Україні - відносно висока густота населення, розвинута мережа автомобільних доріг та задовільне залізничне сполучення, відсутні важкодоступні території із складними ділянками рельєфу (високогір'я, болота, пустелі, острови тощо).

\section{Потенційна та фактична ємність продовольчого ринку областей Причорноморського регіону в 2017р., тис. т відповідної продукції*}

\begin{tabular}{|c|c|c|c|c|c|c|c|c|c|}
\hline \multirow[b]{2}{*}{ Продукт } & \multicolumn{3}{|c|}{$\begin{array}{c}\text { Миколаївська } \\
\text { область }\end{array}$} & \multicolumn{3}{|c|}{ Одеська область } & \multicolumn{3}{|c|}{$\begin{array}{c}\text { Херсонська } \\
\text { область }\end{array}$} \\
\hline & 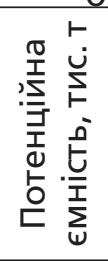 & $\begin{array}{l}\frac{\sigma}{T} \\
\frac{\pi}{5} \\
\frac{5}{\sigma} \\
\theta \\
\theta\end{array}$ & 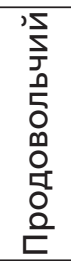 & 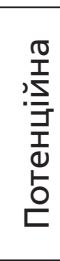 & $\begin{array}{l}\frac{\sigma}{T} \\
\frac{J}{J} \\
\frac{\vec{E}}{\sigma} \\
\tilde{\theta}\end{array}$ & 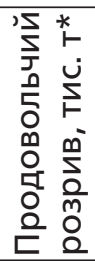 & 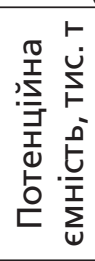 & $\begin{array}{l}\frac{\sigma}{T} \\
\frac{T}{\sigma} \\
\frac{\vec{t}}{\sigma} \\
\theta \\
\theta\end{array}$ & 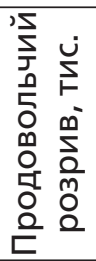 \\
\hline М'ясо і м'ясопродукти & 60,7 & & $-5,6$ & & & $-11,9$ & 55,7 & & 0,1 \\
\hline Молоко і молочні продукти & 343,7 & & & & & & 315,4 & & \\
\hline Яйця, млн. шт. & 252,1 & & & & & & 231,3 & & 50,5 \\
\hline Риба і рибопродукти & 14,9 & & $-2,7$ & & & 4,1 & 13,7 & & $-0,6$ \\
\hline Цукор & 27,5 & & 7,2 & & & 15,7 & 25,2 & & 11,5 \\
\hline Олія та інші рослинні жири & 11,5 & & 3,3 & & & 10,0 & 10,5 & & 1,7 \\
\hline Картопля & 108,8 & & & & & 28,9 & 999 & & 46,7 \\
\hline Овочі і баштанні & 126,0 & & & & & 95,6 & 115,6 & & 56,7 \\
\hline Фрукти, ягоди, горіхи, виноград & 91,7 & & & & & $-53,4$ & 84,1 & & $-33,5$ \\
\hline Хліб і хлібні продукти & 108,8 & & 8,0 & & & 22,4 & 99,9 & & 21,0 \\
\hline
\end{tabular}

*розраховано за даними [15]

** продовольчий розрив = фактична ємність ринку - потенційна ємність ринку 
Лагодієнко В.В. Продовольча безпека Причорноморського регіону: стан, тенденції, перспективи

Виробництво та споживання базових видів продовольства на душу населення в областях Причорноморського регіону в 2017р., у середньому кг на душу в рік*

\begin{tabular}{|c|c|c|c|c|c|c|c|c|c|}
\hline \multirow[b]{2}{*}{ Продовольство } & \multicolumn{3}{|c|}{$\begin{array}{c}\text { Миколаївська } \\
\text { область }\end{array}$} & \multicolumn{3}{|c|}{ Одеська область } & \multicolumn{3}{|c|}{$\begin{array}{l}\text { Херсонська } \\
\text { область }\end{array}$} \\
\hline & & & 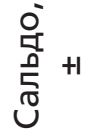 & & & 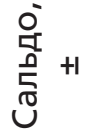 & & & 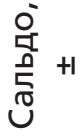 \\
\hline М'ясо і м'ясопродукти & 26,1 & 48,1 & -22 & 18,8 & 48 & & 39 & 53,1 & \\
\hline Молоко і молочні продукти & 298,7 & 202 & 96,7 & & & & 279 & & 74,6 \\
\hline Яйџя,шт. & 220,6 & 261 & $-40,4$ & & 268 & & & 268 & \\
\hline Риба і рибопродукти & 1,6 & 10,6 & -9 & 3,5 & 14,7 & & 3,9 & 12,4 & $-8,5$ \\
\hline $\begin{array}{l}\text { Цукор } \\
\text { Олія та інші рослинні жири }\end{array}$ & $\begin{array}{c}0 \\
2548\end{array}$ & $\begin{array}{l}30,3 \\
12,9\end{array}$ & $\begin{array}{l}-30,3 \\
2419\end{array}$ & 0 & 30,6 & & 0 & 34,9 & \\
\hline Картопля & 1597 & 115,6 & 44,1 & & & 57,7 & & & \\
\hline Овочі і баштаı & 505,5 & 176,4 & 329,1 & & & & & & \\
\hline Фрукти, ягоди, горіхи, виноград & 69,7 & 51,3 & 18,4 & & 57,6 & 86,5 & & 48,1 & 53,7 \\
\hline Хліб і хлібні продукти ** & 1154 & 102 & 1052 & & & & & 115 & \\
\hline
\end{tabular}

* розраховано за даними [15], [18], [19]

**у переводі в зерно

Іншими словами, в контексті забезпечення продовольчої безпеки, у нас відсутня так звана проблема «продовольчої милі» [17, с. 5-7]. Відтак, немає логіки в абсолютній регіональній продовольчій автономії. I хоча економіка більшості регіонів України містить аграрну складову, в кожному випадку особливості сільськогосподарського виробництва мають відповідати територіальній спеціалізації, виходячи із природно-кліматичних умов, якості земельних ресурсів тощо. Отже, наразі в областях Причорноморського регіону дефіцитними видами продовольства $\epsilon:$ м'ясо та м'ясопродукти, риба та рибні продукти, цукор (табл. 5). Решта видів продовольства не $\epsilon$ дефіцитними. Такий стан вказує на порушення принципів територіальної спеціалізації аграрного виробництва:

1) в регіоні має місце значне перевиробництво зернових та зернобобових, тому за логікою тут мало 6 бути зосереджене м'ясне тваринництва. Виходячи із специфіки степової зони - свинарство і птахівництво;

2) виходячи із специфіки степової природно-кліматичної зони, виробництво молока, картоплі мало 6 бути дефіцитним;

3) дефіцитність риби, рибопродуктів у областях Причорноморського регіону підтверджують порушення базових принципів територіальної спеціалізації виробництва.

У виробництві сільськогосподарських товаровиробників Причорноморського регіону домінує вирощування високорентабельних зернових колосових, кукурудзи, сої, соняшнику. Можна припустити, що окрім інших причин, орієнтація на виробництво високоліквідної продукції з коротким циклом зумовлена тим, що ринки даної продукції мають значно вищу ємність через експортну складову. Натомість виробництво тваринницької продукції, риби зорієнтовано переважно на внутрішній ринок (національний і обласний), який має низьку ємність, а тому непривабливий для інвестування. До того ж інвестиції у такі виробництва мають тривалий період окупності, продукція потребує спеціальних умов для виробництва, зберігання, транспортування, що значно підвищує підприємницькі ризики. В результаті, виникає так зване «закляте коло бідності» (рис. 1). Ми вважаємо, що його головною причиною $\epsilon$ низька платоспроможність населення, яка у системі показників продовольчої безпеки країни (регіону) виражається через рівень економічної 


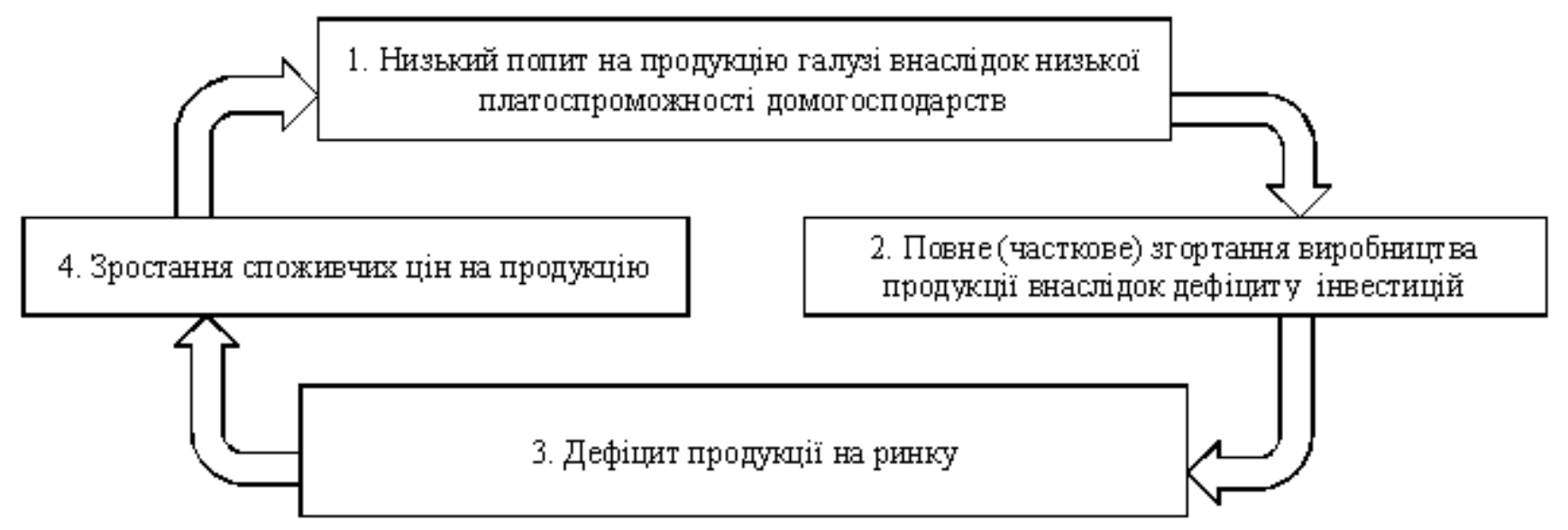

\section{Рис. 1. «Закляте коло бідності» * * розроблено автором}

доступності продовольства. Стало очевидним, що зростання аграрного виробництва не означає автоматичного досягнення продовольчої безпеки країни, регіону, домогосподарства.

Починаючи з 2000р., виробництво сільськогосподарської продукції у Причорноморському регіоні демонструє тенденцію до зростання (рис. 2). Проте рівень економічної доступності продовольства - критично низький. Усе це вказує на те, що як на національному, так і на регіональному рівні необхідно переходити від стимулювання пропозиції аграрної продукції до стимулювання продовольчого попиту. Що особливо актуальну в світлі реформи децентралізації - підвищення не лише прав, але й відповідальності місцевої влади за соціально-економічний стан ввіреної їм території та її громади.

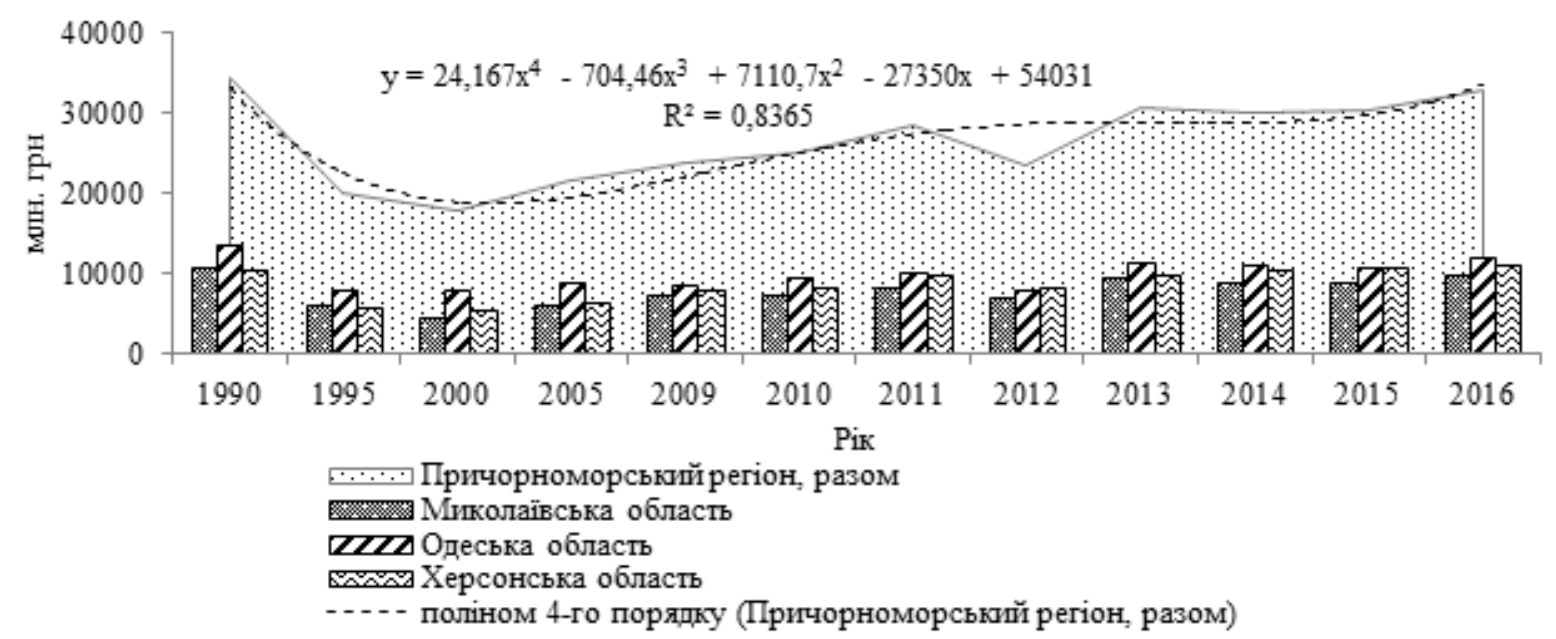

Рис. 2. Виробництво продукції сільського господарства в областях Причорноморського регіону, млн. грн. у постійних цінах *

* побудовано на основі даних $[18,19]$ 
Лагодієнко В.В. Продовольча безпека Причорноморського регіону: стан, тенденції, перспективи

Серед найбільш розповсюджених та таких, що зарекомендували себе прямих практик стимулювання продовольчого попиту можна виділити наступні:

1) програма шкільних обідів - безкоштовних, за пільговою ціною;

2) функціонування благодійних муніципальних продовольчих кухонь (приготування їжі), продовольчих комор (зберігання продовольства), їдалень (безпосереднє харчування) - для продовольчої допомоги безробітним, одино-ким матерям, малозабезпеченим, безхатькам;

3) соціальний патронаж - допомога у купівлі та приготуванні їжі для людей з обмеженими фізичними можливостями;

4) функціонування мережі магазинів із реалізацією продовольчих товарів за пільговими цінами для визначених категорій населення;

5) функціонування програм продовольчої допомоги за прикладом Програми продовольчих талонів США.

Серед непрямих способів стимулювання продовольчого попиту можна виділити:

1) поліпшення національного (регіонального) інвестиційного клімату для створення додаткових робочих місць, сприяння розвитку малого і середнього бізнесу;

2) безкомпромісна антимонопольна політика та посилення відповідальності за порушення Антимонопольного законодавства;

3) сприяння розвитку ринкової інфраструктури (дороги, громадський транспорт, місця масової організованої торгівлі тощо) для розширення схеми торгівлі «місцеве продовольство - місцевому населенню».

Слід визнати, що серйозною перепоною на шляху реалізації програм стимулювання продовольчого попиту $\epsilon$ значний рівень тінізації української економіки. ІІї вплив може дискредитувати, а то й взагалі звести нанівець усі зусилля центральної та місцевої влади, громадських організацій. Адже критично важливо об'єктивно визначити, хто насправді потребує продовольчої допомоги, а хто ні. Тому поряд із розгортанням програм продовольчої допомоги має бути задіяний комплекс заходів, спрямований на легалізацію доходів громадян.

\section{Висновки:}

1) за фактичними значеннями індикатору «добова енергетична цінність раціону людини» рівень продовольчої безпеки в Одеській та Херсонській областях - задовільний, а у домогосподарства I, II і IV децильних груп Миколаївської області - незадовільний;

2) за фактичними значеннями індикаторів «забезпечення раціону людини основними видами продуктів», «економічна доступність продуктів», «ємність внутрішнього ринку окремих продуктів» рівень продовольчої безпеки Причорноморського регіону - незадовільний;

3) в Причорноморському регіоні проблема фізичного доступу до продо-вольства - відсутня: регіон зернопрофіцитний, а дефіцитні види продовольства постачаються з інших областей країни;

4) для досягнення задовільного рівня продовольчої безпеки Причорно-морського регіону необхідно перейти від стимулювання пропозиції аграрної продукції до стимулювання продовольчого попиту.

Перспективним напрямком подальших досліджень із даної тематики $\epsilon$ розробка пропозиції щодо розвитку продуктових підкомплексів продукція яких $\epsilon$ дефіцитною на території Причорноморського регіону, однак розміщення яких тут відповідає принципам територіальної спеціалізації.

\section{Література}

1. Hopkins R. F. Food security, policy options and the evolution of state re-sponsibility / Hopkins R. F., Tullis F. L., Hollist W. L. (eds). - Food, the State and International Political Economy: Dilemmas of Developing Countries. - Lincoln and London: University of Nebraska Press, 1986. - 360p.

2. Maxwell S. Household Food Security: Concepts, Indicators, Measurements / Simon Maxwell, Timothy R. Frankenberger. - New York: United Nations Children's Fund. Rome: International Fund for Agricultural Development, 1992. - 274p.

3. Joachim von Braun. Agriculture, Food Security, Nutrition and the Millennium Development Goals / Joachim von Braun, M. S. Swaminathan, and Mark W. Rosegrant. 
[Електронний ресурс]: International Food Policy Research Institute. - Jun 16, 2005 by Melanie Allen. - Режим доступy: http:// www.ifpri.org/blog/agriculture-food-securitynutrition-and-millennium-development-goals

4. Promoting Regional Trade to Enhance Food Security. A Case Study on the Border Region of Tanzania and Zambia / Daniela Bese, Andrea D chting, Henri Gebauer, Alfred Gerken, Claude Maeda, Victor M. Manyong, Christian Rupschus, Sonia Starosta; team leaders: Victor M. Manyong (IITA) and Alfred Gerken (SLE). Berlin: SLE, 2009. - 134p.

5. Chandra A. C. Regional Food Security and Trade Policy in Southeast Asia: The Role of ASEAN / Alexander C. Chandra and Lucky A. Lontoh // Series on Trade and the Food Security Policy Report 3. June 2010. - 29p.

6. Regional Food Security Reserve / Roger Blein, Raphael Beaujeu and Henri Leturque, Salifou Konat . - ECOWAS. July 2012. - 115p.

7. Regional food security and water in SADC / Francesco Rampa and Lesley-Anne van Wyk // Discussion Paper. - 2014. No. 159. - 62p.

8. Giesler M. Creating the Responsible Consumer: Moralistic Governance Re-gimes and Consumer Subjectivity / Markus Giesler, Ela Veresiu // Journal of con-sumer research. - 2014. Vol. 41. - 18p.

9. Гойчук О. І. Продовольча безпека / О. І. Гойчук. - Житомир: Полісся, 2004. - 348 с. (Монографія).

10. Власов В. І. Методичні підходи щодо оцінки продовольчої безпеки країни / В. І. Власов, В. П. Саблук, М. А. Лисак // Економіка АПК. - 2009. - №8. - С. 43.

11. Мудрак Р. П. Поведінка споживача як чинник продовольчої безпеки домогосподарства / Р. П. Мудрак // Економічний часопис -XXI. - 2014. №3-4(1). - С. 27-30.

12. Агропродовольчий розвиток України в контексті забезпечення продовольчої безпеки: кол. моногр. / [О.В.Шубравська, Л.В. Молдаван, Б.Й.Пасхавер та ін.]; за ред. д-ра екон. наук О.В.Шубравської; НАН України, ДУ "Ін-т екон. та прогнозув. НАН України». - К., 2014. -456 c.
13. Закон України «Про державну підтримку сільського господарства України» // Відомості Верховної Ради (ВВР). - 2009. - №43. C. 638. - [Із змінами та доповненнями].

14. Постанова Кабінету Міністрів України від 5 грудня 2007 року №1379 «Деякі питання продовольчої безпеки» // Офіційний вісник України. 2007. №93. С. 48.

15. Статистичний збірник «Баланси та споживання основних продуктів харчування населенням України 2017» / Державна служба статистики України; відповід. за вип. О. М. Прокопенко. - Київ, 2018. - 59 с.

16. Статистичний збірник «Витрати і ресурси домогосподарств України у 2017 році» Частина I / Державна служба статистики України; відповід. за вип. І. І. Осипова. - Київ, 2015. - 380 c.

17. Slater J. Community Food Security: Position of Dietitians of Canada / J. Slater. Winnipeg: Department of Human Nutritional Sciences University of Mani-toba and International Centre for Infectious Diseases/Canadian Insti-tutes for Health Research Strategic Training Program in Microbiology and Infectious Diseases, 2007. - 13p.

18. Статистичний збірник «Сільське господарство України 2016» / Дер-жавна служба статистики України; відповід. за вип. О. М. Прокопенко. - Київ, 2015. - 379 с.

19. Статистичний збірник «Регіони України 2016» Частина II / Державна служба статистики України; за ред. І. М. Жук. - Київ, 2015. $-681 \mathrm{c}$.

Лагодиенко В.В.

А.э.н., профессор,

заведующий кафедрой маркетинга,

предпринимательства и торговли,

Одесская национальная академия пищевых технологий

Украина, г. Одесса, ул. Канатная, 112, 65039

E-mail: volodymyr@wiktoriya.com

ПРОДОВОЛЬСТВЕННАЯ БЕЗОПАСНОСТЬ ПРИЧЕРНОМОРСКОГО РЕГИОНА: СОСТОЯНИЕ, ТЕНДЕНЦИИ, ПЕРСПЕКТИВЫ 
Лагодієнко В.В. Продовольча безпека Причорноморського регіону: стан, тенденції, перспективи

В статье проведен анализ количественных значений индикаторов продовольственной безопасности трех областей Причерноморского региона - Николаевской, Одесской, Херсонской. Выявлено, что в отчетном периоде в Николаевской и Одесской областях средний показатель энергетической цен-ности потребляемых продуктов питания был выше порогового значения, но - ниже среднего по стране. При этом домохозяйства I, II и IV децильных групп Николаевской области сталкивались с проблемой временного недоедании. Установлено, что пищевой рацион жителей Причерноморского региона - не сбалансирован по основным питательным веществам - не выполняется условие о доле протеинов в пищевом рационе (пища животного происхождения - 55\% от 2500 кал). Ниже нормы потребляются витаминосодержащие продукты питания - свежие фрукты, ягоды и виноград. Отмечается, что в Одесской и Херсонской областях фактическое значение индикатора «доля расходов на продовольствие в структуре совокупных расходов домохозяйств» оказался близким к пороговому значению. Прямым следствием сокращения потребления основных продуктов питания и критически низкого уровня экономической доступности продовольствия для жителей областей Причерноморского региона является низкая фактическая емкость большинстве сегментов продовольственного рынка.

В областях Причерноморского региона дефицитными видами продовольствия являются: мясо и мясопродукты, рыба и рыбные продукты, сахар. Другие виды продовольствия не являются дефицитными. Такое состояние указывает на нарушение принципов территориальной специализации аграрного производства. Выясняется, что, начиная с 2000г., производство сельскохозяйственной продукции в Причерноморском регионе демонстрирует тенденцию к росту. Однако уровень экономической доступности продовольствия - критически низкий.

Исходя из этого, делается вывод, что для достижения удовлетворительного уровня продовольственной безопасности Причерноморского региона необходимо перейти от стимулирования предложения аграрной продукции к стимулированию продовольственного спроса. Также перспективным является развитие продуктовых подкомплексов дефицитной продукции, размещение которых соответствует принципам территориальной специализации.

Ключевые слова: продовольственная безопасность, регион, домохозяйство, энергетическая ценность, временный голод, экономическая доступность, продовольственная помощь.

\section{Lagodiienko V. \\ Doctor of Economics, Professor, Head of \\ Department of marketing, business and trade, \\ Odessa National Academy of Food Technologies \\ Ukraine, Odessa, street. Kanatna, 112, E-mail: volodymyr@wiktoriya.com}

\section{FOOD SECURITY OF THE BLACK SEA REGION: STATE, TRENDS, PROSPECTS}

In the article was made the analysis of quantitative values of indicators of food security of the three regions of the Black Sea region Mykolaiv, Odesa, Kherson. It was found that during the reporting period in Mykolaiv and Odesa regions the average indicator of the energy value of consumed food was higher than the threshold but - lower than the national average. At the same time households of the 1st, 2nd and 4th decile groups of the Mykolaiv region faced a problem of temporary malnutrition. It is revealed that the diet of the inhabitants of the Black Sea region is not balanced by the main nutrients, is not satisfied the condition of the share of proteins in the diet (animal food - 55\% from 2,500 cal). Below the norm are consumed vitamin-containing food products - fresh fruits, berries and grapes. It is noted that in Odesa and Kherson regions, the actual value of the indicator "share of food expenses in the structure of total household expenditures» turned out to be close to the threshold value. The direct consequence of a reduction in the consumption of basic foodstuffs and a critically low level of economic availability of food for the inhabitants of the territories of 
most segments of the food market. In the regions of the Black Sea region, scarce food is: meat and meat products, fish and fish products, sugar. Other types of food are not scarce. This state indicates violation of the principles of territorial specialization of agrarian production. It turns out that since 2000 , the production of agricultural products in the Black Sea region has a tendency to increase. However, the level of economic availability of food is critically low. Therefore, it is concluded that in order to achieve a satisfactory level of food security in the Black Sea region, it is necessary to move from stimulating the supply of agrarian products to stimulating the food demand. Also promising is the development of grocery subcomplexes of deficient products, the placement of which corresponds to the principles of territorial specialization.

Key words: food security, region, household, energy value, temporary hunger, economic accessibility, food aid.

\section{References}

1. Hopkins, R. F., Tullis, F. L., Hollist, W. L. (Eds.) (1986). Food, the State and International Political Economy: Dilemmas of Developing Countries. Lincoln and London: University of Nebraska Press.

2. Maxwell, S., Frankenberger, T. R. (1992). Household Food Security: Concepts, Indicators, Measurements. New York: United Nations Children's Fund, Rome: International Fund for Agricultural Development.

3. von Braun, J., Swaminathan, M. S., Rosegrant, M. W. (2005). Agriculture, Food Security, Nutrition and the Millennium Development Goals. International Food Policy Research Institute. Jun 16, 2005 by Melanie Allen. Retrieved from http://www.ifpri.org/ blog/agriculture-food-security-nutrition-andmillennium-development-goals

4. Manyong, V. M., Gerken, A. (Eds.) (2009). Promoting Regional Trade to Enhance Food Security. A Case Study on the Border Region of Tanzania and Zambia. Berlin: SLE.

5. Chandra, A. C., Lontoh, L. A. (2010). Regional Food Security and Trade Policy in Southeast Asia: The Role of ASEAN. Series on Trade and the Food Security, Policy Report 3, 29.

6. Blein, R., Beaujeu, R., Leturque $H_{\text {., }}$ Konat , S. (2012). Regional Food Security Reserve. ECOWAS, 115.
7. Rampa, F., van Wyk, L.-A. (2014). Regional food security and water in SADC. Discussion Paper, 159, 62.

8. Giesler, M., Veresiu, E. (2014). Creating the Responsible Consumer: Moralistic Governance Regimes and Consumer Subjectivity. Journal of consumer research, 41, 18.

9. Hoichuk, O. I. (2004). Food security. Zhytomyr: Polissia.

10. Vlasov, V. I., Sabluk, V. P., Lysak, M. A. (2009). Methodological ap-proaches to assessment of the food security of country. The economy of AIC, (8), 43-45.

11. Mudrak, R. P. (2014). Consumer behavior as a factor of the food security of household. Economic annals - XXI, 3-4(1), 27-30.

12. Shubravska, O.V., Moldavan, L.V., Paskhaver, B.I. (2014). Agri-food development of Ukraine in the context of food security. Kiev: National Academy of Sciences of Ukraine, Government agency «Institute of Economics and Forecasting of NASU".

13. Verkhovna Rada of Ukraine (2009). About the State Support of Agriculture of Ukraine (The Low of Ukraine). Vidomosti Verkhovnoi Rady, 43, 638.

14. Government of Ukraine (2007). Some issues of food security (Decree). Ofitsiinyi visnyk Ukrainy, 93, 48.

15. Balances and consumption of basic foodstuffs population of Ukraine in 2017. (2016). Statistical Yearbook. Kyiv: State Statistics Service of Ukraine (in Ukr.).

16. Expenditure and resources of households of Ukraine in 2017. (2016). Statistical Yearbook. Kyiv: State Statistics Service of Ukraine (in Ukr.).

17. Slater, J. (2007). Community Food Security: Position of Dietitians of Canada. Winnipeg: Department of Human Nutritional Sciences University of Manitoba and International Centre for Infectious Diseases/ Canadian Institutes for Health Research Strategic Training Program in Microbiology and Infectious Diseases

18. Agriculture of Ukraine in 2016. (2017). Statistical Yearbook. Kyiv: State Statistics Service of Ukraine (in Ukr.).

19. Regions of Ukraine in 2016. Part II. (2017). Statistical Yearbook. Kyiv: State Statistics Service of Ukraine (in Ukr.). 